University of Nebraska - Lincoln

DigitalCommons@University of Nebraska - Lincoln

Publications, Agencies and Staff of the U.S.

Department of Commerce

U.S. Department of Commerce

$7-2008$

\title{
False Killer Whales (Pseudorca crassidens) Around the Main Hawaiian Islands: Long-Term Site Fidelity, Inter-Island Movements, and Association Patterns
}

\author{
Robin Baird \\ Cascadia Research Collective \\ Antoinette Gorgone \\ NOAA Southeast Fisheries Science Center \\ Daniel McSweeney \\ Wild Whale Research Foundation \\ Daniel Webster \\ Wild Whale Research Foundation \\ Dan Salden \\ Hawai'i Whale Research Foundation \\ See next page for additional authors \\ Follow this and additional works at: https://digitalcommons.unl.edu/usdeptcommercepub \\ Part of the Environmental Sciences Commons
}

Baird, Robin; Gorgone, Antoinette; McSweeney, Daniel; Webster, Daniel; Salden, Dan; Deakos, Mark; Ligon, Allan; Schorr, Gregory; Barlow, Jay; and Mahaffy, Sabre, "False Killer Whales (Pseudorca crassidens) Around the Main Hawaiian Islands: Long-Term Site Fidelity, Inter-Island Movements, and Association Patterns" (2008). Publications, Agencies and Staff of the U.S. Department of Commerce. 37. https://digitalcommons.unl.edu/usdeptcommercepub/37

This Article is brought to you for free and open access by the U.S. Department of Commerce at DigitalCommons@University of Nebraska - Lincoln. It has been accepted for inclusion in Publications, Agencies and Staff of the U.S. Department of Commerce by an authorized administrator of DigitalCommons@University of Nebraska - Lincoln. 


\section{Authors}

Robin Baird, Antoinette Gorgone, Daniel McSweeney, Daniel Webster, Dan Salden, Mark Deakos, Allan Ligon, Gregory Schorr, Jay Barlow, and Sabre Mahaffy 


\title{
False killer whales (Pseudorca crassidens) around the main Hawaiian Islands: Long-term site fidelity, inter-island movements, and association patterns
}

\author{
ROBIN W. BAIRD
}

Cascadia Research Collective, 218 $\frac{1}{2}$ West 4th Avenue, Olympia, Washington 98501, U.S.A.

E-mail: rwbaird@cascadiaresearch.org

\section{ANTOINETTE M. GORGONE}

NOAA Southeast Fisheries Science Center, 101 Pivers Island Road, Beaufort, North Carolina 28516, U.S.A.

\section{DANIEL J. MCSWEENEY}

DANIEL L. WEBSTER

Wild Whale Research Foundation, P. O. Box 139, Holualoa, Hawai i 96725 , U.S.A.

\section{DAN R. SALDEN}

Hawai'i Whale Research Foundation, 52 Cheshire Drive, Maryville, Illinois 62062-1931, U.S.A.

\section{Mark H. DEAKos}

The Hawai i Association for Marine Education and Research, Inc., PMB \#175, 5095 Napilihau Street 109B,

Lahaina, Hawai'i 96761, U.S.A.

\section{ALLAN D. LIGON}

Hawaiian Islands Humpback Whale National Marine Sanctuary, 726 South Kihei Road,

Kihei, Hawai'i 96753 , U.S.A.

\section{GREGORY S. SCHORR}

Cascadia Research Collective,

218 $\frac{1 / 2}{2}$ West 4th Avenue, Olympia, Washington 98501, U.S.A.

\section{JAY BARLOW}

NOAA Southwest Fisheries Science Center, 8604 La Jolla Shores Drive,

La Jolla, California 92037, U.S.A.

\section{SABRE D. MAHAFFY}

Cascadia Research Collective,

218 $\frac{1}{2}$ West 4th Avenue, Olympia, Washington 98501,U.S.A. 
and

Wild Whale Research Foundation,

Box 139, Holualoa, Hawai'i 96725, U.S.A.

\begin{abstract}
Despite their world-wide distribution throughout the tropics and subtropics, false killer whales (Pseudorca crassidens) are one of the lesser-known large odontocetes. Genetic evidence indicates a demographically isolated population around the main Hawaiian Islands. We examine site fidelity, movements and association patterns in this population using data from directed surveys and opportunistic photographs from 1986 to 2007 . This species was only infrequently encountered, and while found in depths from 38 to $4,331 \mathrm{~m}$, sighting rates were greatest in depths $>3,000 \mathrm{~m}$. We photo-identified 152 distinctive individuals. Resighting rates were high, with an average of $76.8 \%$ of distinctive individuals within groups documented on more than one occasion. Most ( $86.6 \%)$ were linked by association into a single social network; only one large group (16 distinctive individuals), documented the farthest offshore $(42-70 \mathrm{~km})$, did not link by association to that large network, and may be part of an offshore population. Individual movements of up to $283 \mathrm{~km}$ were documented, with a large proportion of individuals moving among islands. Individuals were resighted up to $20.1 \mathrm{yr}$ after first being documented, showing long-term fidelity to the islands. Repeated associations among individuals were documented for up to 15 $\mathrm{yr}$, and association analyses indicate preferred associations and strong bonds among individuals.
\end{abstract}

Key words: false killer whale, Pseudorca crassidens, site fidelity, social organization, Hawai'i, movements.

Our understanding of cetacean biology and ecology has increased dramatically over the last $40 \mathrm{yr}$, although much of this increase has come from studies of just a few species. Research on baleen whales has focused primarily on those that inhabit nearshore waters or were impacted heavily by historical whaling, and research on toothed whales has focused primarily on those species that inhabit coastal temperate waters. In general, much less is known about the biology of open-ocean or tropical species, due to the logistics of working with open-ocean populations and the relative lack of economic support for research in many tropical countries. False killer whales (Pseudorca crassidens) are one of these poorly known tropical oceanic species (Stacey et al. 1994, Odell and McClune 1999). They are distributed worldwide throughout the tropics and at least occasionally in warm temperate areas, but in most parts of their range they are typically seen far from shore. With their tendency to strand on beaches, most of what is known about the biology of false killer whales comes from examination of stranded animals (Stacey et al. 1994, Odell and McClune 1999). Studies of individual movements and social organization have been limited. AcevedoGuitierrez et al. (1997) observed false killer whales 15 times at two sites off Costa Rica and photo-identified individuals, noting some repeated associations among individuals for periods of up to $2 \mathrm{yr}$.

With the exception of occasional individuals that appear outside of the normal range of this species (e.g., Stacey and Baird 1991), the primary areas where false 
killer whales are frequently seen close to shore are tropical oceanic islands (e.g., Acevedo-Guitierrez et al. 1997). There is considerable interest in the population of false killer whales in Hawaiian waters due to interactions with fisheries (Baird and Gorgone 2005). False killer whales interact with the Hawai' i-based long-line fishery, which operates in waters greater than approximately $46 \mathrm{~km}$ from the Hawaiian Islands. Individuals are known to take hooked tunas and other fish off longlines, and some individuals are occasionally killed or seriously injured when hooked during this process (Forney and Kobayashi 2007). The population of false killer whales within the Hawai'i Exclusive Economic Zone (EEZ) is relatively small. Barlow (2006) provided an estimate for the entire Hawai' $\mathrm{i}$ EEZ, an area of approximately 2.4 million $\mathrm{km}^{2}$, of only 236 individuals $(\mathrm{CV}=1.13)$ based on a large-vessel line transect survey in 2002. Using combined data from the 2002 survey and another in 2005, Barlow and Rankin (2007) reestimated the Hawaiian EEZ population to be 484 individuals $(\mathrm{CV}=0.93)$. Although the absolute number of false killer whales estimated to be killed or seriously injured in the longline fishery is small, the rate of serious injury and mortality is estimated to be greater than the "Potential Biological Removal" (PBR) level for that population (Carretta et al. 2006), and thus the population is considered "strategic" by NOAA Fisheries Service, the U.S. agency responsible for management of cetaceans. Using genetic analyses of biopsy samples collected both around the main Hawaiian Islands (the eight large islands in the eastern part of the Hawaiian Island chain) and elsewhere in the tropical Pacific, Chivers et al. (2007) provide evidence that false killer whales around the main Hawaiian Islands are genetically differentiated from false killer whales sampled elsewhere. However, whether there is a clear geographic boundary between island-associated and offshore false killer whales is unknown, and how far from shore island-associated false killer whales extend is also unknown. Baird and Gorgone (2005) suggested that the false killer whales associated with the main Hawaiian Islands did interact with the offshore longline fishery based on dorsal fin disfigurements possibly caused by longline interactions, although it is possible such disfigurements resulted from long-line interactions in the past, when the fishery operated closer to shore.

Around the main Hawaiian Islands, false killer whales are encountered so infrequently (Baird and Gorgone 2005) that directed research focused solely on this species would be extremely time-consuming and expensive. The good working conditions off the western (leeward) sides of the main Hawaiian Islands has encouraged studies of other more frequently encountered cetacean species, and these studies have allowed collection of information on more rarely encountered species such as false killer whales. Here we use photographic data on false killer whales around the main Hawaiian Islands obtained from both directed odontocete surveys and opportunistic efforts, to explore aspects of the biology of this poorly known species. We examine inter-island movements among the main Hawaiian Islands, assess site fidelity over a 21-yr period, and explore association patterns of individuals as it pertains to understanding small-scale population structure and social organization in this species.

\section{METHODS}

Directed surveys for odontocetes were undertaken around all the main Hawaiian Islands from 2000 through 2006, with efforts off different islands in two to five different years over the 7 -yr period. These efforts were non-random, non-systematic 
surveys that attempted to cover as wide a survey area and as broad a range of depths as possible, given weather and fuel constraints. Surveys were typically based from one island at a time for periods of 2-6 wk, with the exception of one survey, in May/June 2003, that covered the waters around all the main islands over a 6-wk period. Research vessels varied, but the majority of effort was undertaken from vessels from 5.8 to $8.2 \mathrm{~m}$ long, with two to six observers scanning $360^{\circ}$ around each survey vessel. Vessels surveyed at speeds of $15-30 \mathrm{~km} / \mathrm{h}$. Other research vessels or whale watching operators would occasionally report sightings; when groups of odontocetes were approached in response to these sightings the sighting cue was noted as a "radio call." Surveys were largely restricted to areas with sea conditions of Beaufort 3 or less. Survey effort was documented with locations recorded every 5 min using a global positioning system (GPS), and sea state was recorded when it changed. During directed surveys observed groups of odontocetes were approached for species identification, to estimate group size, and to record location (using a GPS).

Attempts were made to photo-identify all individuals in all groups of false killer whales encountered. Reasons for terminating encounters (time of day, weather, group lost, or all individuals identified) were noted. Associations with other cetacean and seabird species were documented, as well as observations of predation on fish. Biopsy samples for genetic studies were collected from some groups; results of this work are reported by Chivers et al. (2007).

Information from directed surveys was used to examine group size, sighting depths in relation to survey effort, and relative encounter rates. Relative encounter rates were calculated both using all sightings and excluding sightings originating from radio calls. For sighting and 5-min effort locations, depths were determined by overlaying the point location data on a bathymetric raster surface in ArcGIS 9.1 (ESRI). Underlying depth values (in meters) were transferred to point locations using the "intersect point tool" in Hawth's analysis tools (Beyer 2004). We used a gridded $50 \mathrm{~m} \times 50 \mathrm{~m}$ multibeam synthesis bathymetry model from the Hawai'i Mapping Research Group. ${ }^{1}$ The model had areas of no data, so the grid was overlaid on 3-arc s $(90 \mathrm{~m} \times 90 \mathrm{~m})$ U.S. Coastal Relief Model bathymetry from the National Geophysical Data Center ${ }^{2}$ to provide $90 \mathrm{~m}$ resolution data where $50 \mathrm{~m}$ resolution data were absent. Sighting rates in relation to effort by depth were calculated using 500-m depth bins (e.g., 1-500 m, 501-1,000 m, etc.).

False killer whale photographs were also obtained from a number of other sources: (1) opportunistically during humpback whale (Megaptera novaeangliae) research in the "4-island" area (around the islands of Moloka i, Lana 'i, Maui, and Kaho'olawe) from 2003 through 2006 (DRS, MHD, ADL); (2) during a large-scale line transect survey ranging from the main Hawaiian Islands to Palmyra and Johnston Atoll in 2005 (PICEAS; see Barlow and Rankin 2007); and (3) from photographs taken off the island of Hawai'i during research on short-finned pilot whales (Globicephala macrorbynchus) and other species from 1986 through 2006 (see McSweeney et al. 2007). In addition, 10 identifications from eight additional encounters were provided by several whale or dolphin watching operators, private individuals, or other researchers (1999-2007).

Within encounters, photographs were sorted by individual using a variety of characteristics. Clearly distinct individuals were sorted using body scars, notches on or immediately adjacent to the dorsal fin, and major dorsal fin disfigurements (see Baird

\footnotetext{
${ }^{1}$ Available from http://www.soest.hawaii.edu/HMRG/Multibeam/index.php.

${ }^{2}$ Available from http://www.ngdc.noaa.gov/mgg/coastal/coastal.htm.
} 
and Gorgone 2005). Other individuals were identified within encounters using subtle differences in dorsal fin shape, and/or relative size (i.e., animals that are obviously small calves or neonates based on relative size in photographs where adult individuals were in the same photographic frame). For determining the number of neonates or small calves (that were unmarked) within a group, close associations with identifiable adults were used (i.e., if two or more identifiable adults each had a neonate in close attendance, each neonate was counted separately).

For every individual within each encounter, the best photograph obtained was given a photo quality rating as: poor, fair, good, or excellent, based on the focus, size, and angle of the body relative to the photographic frame, and proportion of the body visible. Each individual was assigned one of four "distinctiveness" categories: not distinctive, slightly distinctive, distinctive, or very distinctive. Those considered "not distinctive" included individuals with no notches on the dorsal fin or scratches on the body (typically neonates or small calves), as well as those with body scratches or extremely small notches that would usually allow for identification within an encounter with excellent quality photographs, but not between encounters. Slightly distinctive animals typically had one or two small notches on the trailing edge of the dorsal fin that allowed for identification within and between encounters, but required excellent quality photographs. Distinctive animals had multiple notches on the fin and could be identified among encounters with fair, good, or excellent quality photographs, while very distinctive animals had multiple notches, distinctive fin shapes, or major fin disfigurements (see Baird and Gorgone 2005), and/or multiple large notches that would allow for matching individuals among encounters even with poor quality photographs. The program Finscan 1.6.1 (Hillman et al. 2003) was used to assist in matching individuals between encounters. Matches between encounters were based on fin shape, and the number, size, shape, and relative positioning of dorsal fin notches. All matches of individuals were agreed upon by at least two experienced matchers. Matches of some individuals were made where notch number, size, or shape were different (i.e., individuals with mark changes). These matches were based on fin shape and individuals having at least two or more marks in common (i.e., with the same size, shape, and relative positioning on the fin). All matches of individuals with mark changes were confirmed by a third experienced matcher. Due to the small number of photographs available from Palmyra and offshore waters we used photographs of all qualities and distinctiveness ratings to assess movements between these areas and the main Hawaiian Islands. Within encounters, all photos were used to estimate the proportion of animals within groups that were "distinctive." For all other analyses (i.e., mark change rates, seasonality of resightings, association analyses, movements among islands, intervals among resightings), only those individuals considered "distinct" or "very distinct" with photo quality ratings of good or excellent were used. Capturerecapture estimates of abundance will be presented elsewhere.

For association analyses, groups were defined as all individuals seen in an area on a single day. While this definition is much broader than is typically used for odontocete association analyses, for Hawaiian false killer whales it seems appropriate for several reasons. Despite extensive survey effort (see Results), false killer whales were only infrequently encountered. When encountered however, small subgroups were often spread out over a broad area, separated by $2-10 \mathrm{~km}$ or more. Subgroups were generally moving through the area in a consistent direction and at similar speeds as a loose association. Extended encounters $(>4 \mathrm{~h}$ ) with multiple subgroups have shown that subgroups intermix throughout an encounter (Baird unpublished). Association 
levels were assessed with Socprog $2.3,{ }^{3}$ using a simple ratio index of association (Cairns and Schwager 1987, Ginsberg and Young 1992), with values ranging from 0 (for individuals that are never seen together) to 1 (for individuals that are always seen together). Calculations of mean and maximum association indices, and tests for preferred/avoided associations (following Bejder et al. 1998) included only individuals seen on three or more occasions. Tests for preferred/avoided associations compared the real association indices against 20,000 randomly permuted variations. $P$ values were determined based on the proportion of the 20,000 permutations that had higher SDs of the association indices than the SD of the real association indices, thus $P$ values that were large $(P>0.95)$ indicated a significant difference. Socprog was used to produce a sociogram showing associations among individuals seen on three or more occasions. Sample sizes were insufficient for quantitative examination of temporal trends in association patterns, however, the time frames for repeated associations among individuals were noted. Social network diagrams were produced with Netdraw 2.043 (Analytic Technologies, Needham, MA). To examine the likelihood of individuals within encounters having multiple records within our catalog, we calculated the percentage of distinct and very distinct individuals within each encounter that were seen on more than one occasion.

To assess whether individuals used the study area year-round, we examined seasonal distribution of sightings of individuals seen on four or more occasions. Sighting months were classified as oceanographic seasons based on Flament (1996): winter (February-April), spring (May-July), summer (August-October), and fall (November-January).

\section{RESULTS}

In directed efforts, a total of $38,759 \mathrm{~km}$ of trackline was covered over $369 \mathrm{~d}$ on the water (2,635 h of survey effort), from 2000 through 2006. Directed efforts covered all months of the year except August, although the amount of effort per month varied from $3.3 \%$ to $15.7 \%$ of the total survey days (median $=8 \%$ ). While the majority $(53.4 \%)$ of search effort was in depths of $1,000 \mathrm{~m}$ or less, search effort extended to almost 5,000 m depth (Fig. 1) and covered all the main Hawaiian Islands (Fig. 2). The total survey area covered was approximately $17,000 \mathrm{~km}^{2}$. Almost all search effort $(93.2 \%)$ was in sea states of Beaufort 3 or less, with the majority (76\%) in Beaufort 2 or less. Average sea states were similar across the entire depth range surveyed.

During directed efforts there were 849 sightings of odontocetes of which $18(2.1 \%)$ were false killer whales, the 11th most frequently encountered species of odontocete (of 16 species observed). Six of 18 sightings of false killer whales, and 22 sightings of seven other species, were initiated due to radio calls from other vessels; excluding all sightings initiated due to radio calls, false killer whales represented only $1.46 \%$ of odontocete sightings (and remained the 11th most frequently encountered species of odontocete). False killer whales were sighted in depths from 38 to 4,331 m (median $=1,011 \mathrm{~m}$ ), ranging from $1.6 \mathrm{~km}$ to $50.5 \mathrm{~km}$ from shore $($ median $=10.0$ $\mathrm{km})$. One encounter was only a brief ( $1 \mathrm{~min}$ ) sighting of a single animal; group sizes for the remaining 17 encounters ranged from 3 to an estimated 41 individuals (median $=15$ individuals). Eight of these 17 encounters were terminated due to

\footnotetext{
${ }^{3}$ Dalhousie University, Halifax, Nova Scotia, Canada. Available from myweb.dal.ca/ hwhitehe/ social.htm.
} 

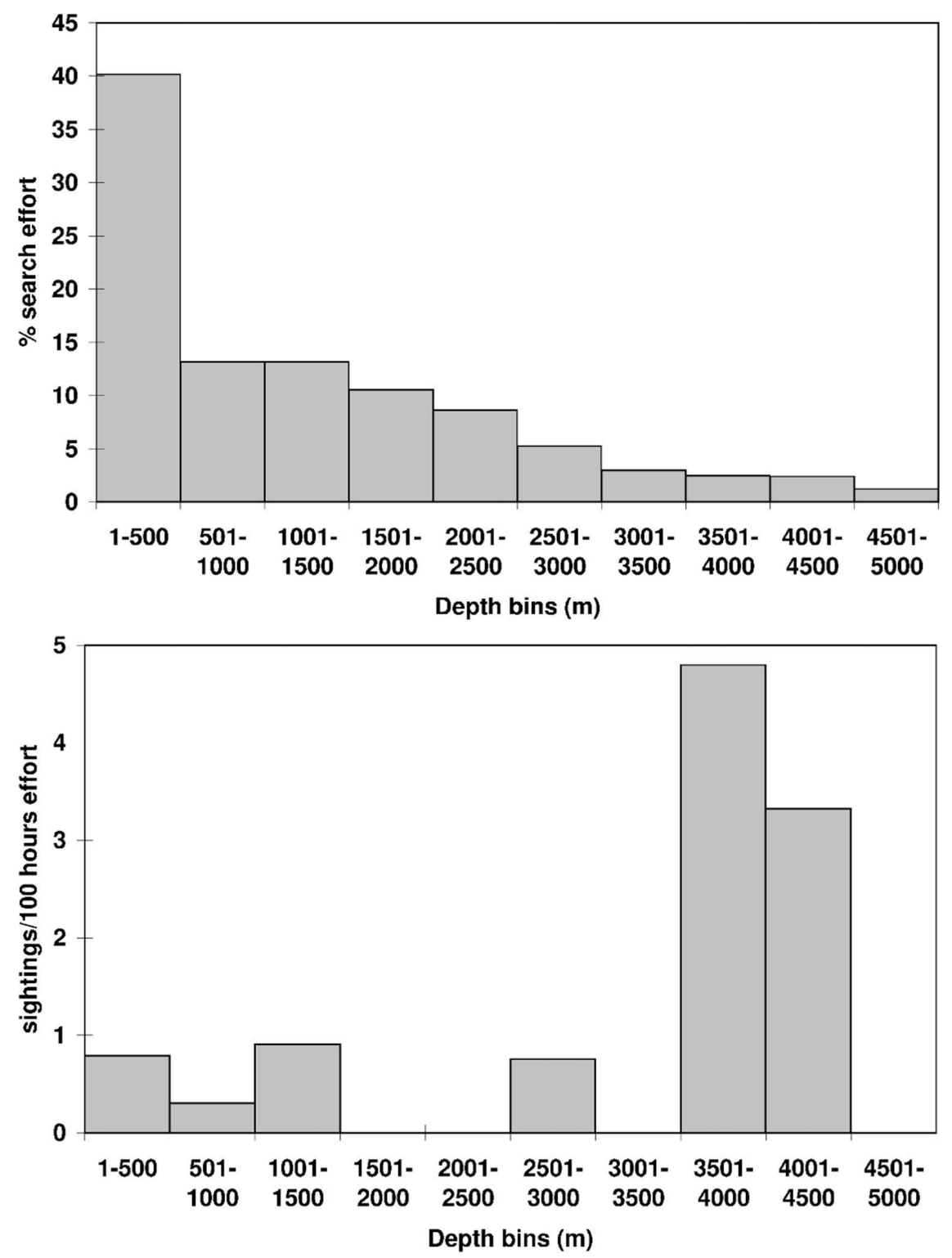

Figure 1. Top. Distribution of search effort in relation to depth from dedicated efforts (depth "bins" of $500 \mathrm{~m}$ ). Bottom. False killer whale sightings per $100 \mathrm{~h}$ search effort by depth bin.

inclement weather or time of day, and three groups were lost. Encounter durations ranged from 0.8 to $7.9 \mathrm{~h}$ (median $=3.0 \mathrm{~h}, n=17$ ). For short duration encounters, group size estimates may not reflect actual group sizes. There was a significant positive relationship between group size and encounter duration (regression $P=0.016$, $r^{2}=0.33, n=17$ ); group sizes for encounters $<2 \mathrm{~h}$ ranged from 3 to 15 individuals 


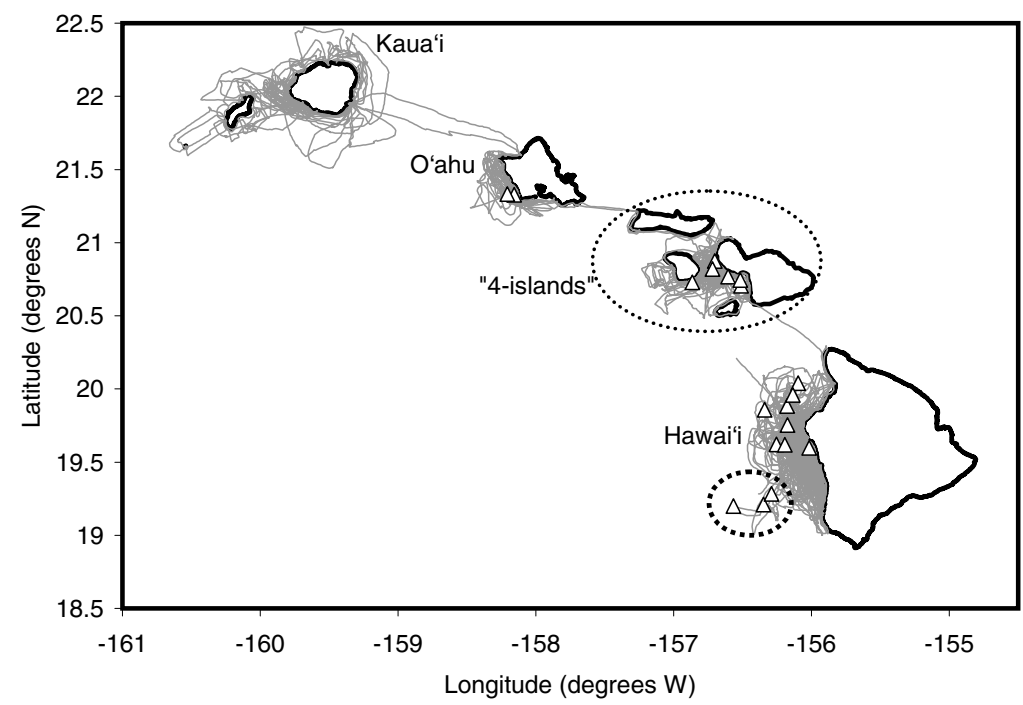

Figure 2. Search effort (lines) from directed odontocete surveys around the main Hawaiian Islands (2000-2006) with false killer whale sightings (triangles). The 4-island area includes Moloka'i, Lana'i, Maui, and Kaho'olawe. Photographs from other sources around the main Hawaiian Islands were in areas covered by search effort from directed odontocete surveys. Three subgroups seen on one day 42-70 km offshore of the island of Hawai $i$, with no links by associations to other groups, are indicated by the heavy dashed oval.

(median $=8.5$ ), while group sizes for encounters $>2 \mathrm{~h}$ ranged from 12 to 41 (median $=25$ ). Larger groups were typically comprised of several smaller subgroups of individuals spread out over $20 \mathrm{~km}$ or more, with clusters all traveling in the same direction at approximately the same speed.

Associations with other species of cetaceans were documented in seven encounters, three with bottlenose dolphins (Tursiops truncatus), two with rough-toothed dolphins (Steno bredanensis), and one each with pygmy killer whales (Feresa attenuata) and humpback whales. For associations with bottlenose and rough-toothed dolphins these species were seen in close association (less than one body length) with false killer whales and associations were prolonged, rather than just one group passing another. Associations with seabirds were documented in five encounters; species recorded feeding in association with false killer whales included brown booby (Sula leudogaster), red-footed booby (S. sula), great frigatebird (Fregata minor), wedge-tailed shearwater (Puffinus pacificus), and sooty tern (Sterna fuscata). Predation on three species of fish was documented on 19 occasions: mahi mahi (Coryphaena hippurus), representing 17 of 19 events; ono or wahoo (Acanthocybium solanderi), with one event; and a deepwater pomfret (probably a monchong, Eumegistus illustrus). While not systematically recorded, predation events and predatory attacks were also noted anecdotally during opportunistic research efforts. Species and approximate number of fish observed being consumed include five or six yellowfin tuna (Thunnus albacares), two or three skipjack tuna (Katsuwonus pelamis), single observations of predation on albacore tuna (T. alalunga) and file fish (probably Aluteus scriptus), and multiple ( $>20)$ observations of predation on mahi mahi. Two attacks on broadbill swordfish (Xiphias gladius) were also observed, although the whales were not observed killing either. 
Table 1. Number of false killer whale encounters and identifications (including resightings) by year and area.

\begin{tabular}{|c|c|c|c|c|c|c|}
\hline \multirow[b]{2}{*}{ Year } & \multicolumn{5}{|c|}{ Number of encounters (identifications) by area and year } & \multirow[b]{2}{*}{ Total } \\
\hline & Kaua'i & O’ahu & 4-islands & Hawai'i & $\overline{\text { Palmyra }}$ & \\
\hline 1986 & - & - & - & $3(12)$ & - & $3(12)$ \\
\hline 1987 & - & - & - & $3(16)$ & - & $3(16)$ \\
\hline 1988 & - & - & - & $1(5)$ & - & $1(5)$ \\
\hline 1990 & - & - & - & $2(23)$ & - & $2(23)$ \\
\hline 1991 & - & - & - & $1(3)$ & - & $1(3)$ \\
\hline 1993 & - & - & - & $1(4)$ & - & $1(4)$ \\
\hline 1995 & - & - & - & $1(1)$ & - & $1(1)$ \\
\hline 1998 & - & - & - & $1(6)$ & - & $1(6)$ \\
\hline 1999 & - & - & $1(1)$ & $1(6)$ & - & $2(7)$ \\
\hline 2000 & - & - & $4(20)$ & - & - & $4(20)$ \\
\hline 2001 & - & - & $2(22)$ & - & - & $2(22)$ \\
\hline 2002 & - & $1(1)$ & - & $1(5)$ & - & $2(6)$ \\
\hline 2003 & - & $1(20)$ & $2(10)$ & - & - & $3(30)$ \\
\hline 2004 & - & - & $1(7)$ & $6(58)$ & - & $7(65)$ \\
\hline 2005 & - & - & $4(29)$ & $2(7)$ & $1(1)$ & $7(37)$ \\
\hline 2006 & $1(1)$ & $1(2)$ & $3(28)$ & $4(24)$ & - & $10(55)$ \\
\hline 2007 & - & - & - & $1(1)$ & - & $1(1)$ \\
\hline Sum & $1(1)$ & $3(23)$ & 17 (117) & $28(171)$ & $1(1)$ & $50(313)$ \\
\hline
\end{tabular}

Analyses are restricted to distinct and very distinct individuals with good or excellent quality photos.

Identification photographs were available from 17 of the 18 encounters from directed efforts around the main Hawaiian Islands. Photographs were available from 44 additional encounters from 1986 through February 2007, 40 of which were from the main Hawaiian Islands, three were from Palmyra (approximately 1,300 km SSW of the main Hawaiian Islands), and one was from an area approximately half way between Palmyra and Johnston Atoll (approximately 1,100 km SW of the main Hawaiian Islands, Table 1).

Examples of the marks used in matching are illustrated in Figure 3. From photographic matching within encounters there were 484 identifications of individuals of all photo qualities and distinctiveness ratings. Seventy-eight identifications were of individuals considered "not distinctive." Excluding these, the identifications represented a maximum of 203 individuals, 194 from the main Hawaiian Islands and 9 from Palmyra/offshore. The mean proportion of individuals within groups that were considered distinctive or very distinctive was $73.7 \%$ ( $\mathrm{SD}=22.8 \%, n=61$ groups). Individuals that were considered "distinctive" or "very distinctive" had up to 13 notches on the dorsal fin (median $=5$; Fig. 3). Using only distinctive and very distinctive individuals with photo qualities of good or excellent reduced the total number of identifications to 313, from 51 different encounters ( 50 around the main Hawaiian Islands, 1 off Palmyra). Number of photographs available for these 313 identifications ranged from 1 to 124 (median $=8$, sum $=4,819$ ). The number of identifications of this type per encounter ranged from 1 to 21 (median $=6$ ) from directed efforts, and 1 to 24 (median $=3$ ) from opportunistic efforts.

From the 313 identifications there were 153 unique individuals most (152) of which were from around the main Hawaiian Islands. This number should not be 
viewed as a minimum population size, as the identifications were obtained over a 21-yr period and there were likely a number of mortalities (and births) during that period. As well, it is possible that some individuals had mark changes to the point where they were no longer recognizable. However, the low rate of mark change documented (see below) and restricting our analyses to distinctive and very distinctive individuals (with a mean of 5.81 dorsal fin notches/individual, $\mathrm{SD}=2.39$ ) should minimize this possibility. While on average there were 2.04 identifications per unique individual, of the 152 individuals from around the main Hawaiian Islands, just over half ( 80 individuals, $52.6 \%$ ) were seen on more than one occasion. Those seen more than once were seen an average of 3.0 times each $(\mathrm{SD}=1.38$, maximum $=8$ times) and 69 (45.4\% of those documented around the main Hawaiian Islands) were seen in more than $1 \mathrm{yr}$. On a group basis, the proportion of distinctive and very distinctive individuals within groups that were documented on more than one occasion over the study was $76.8 \%$ ( $\mathrm{SD}=33.2 \%$; median $=100 \%, n=51$ ). Excluding the group of 16 individuals seen $42-70 \mathrm{~km}$ offshore of the island of Hawai i (for which there were no matches to any other group), the largest group for which there were no matches to other groups was of two individuals.
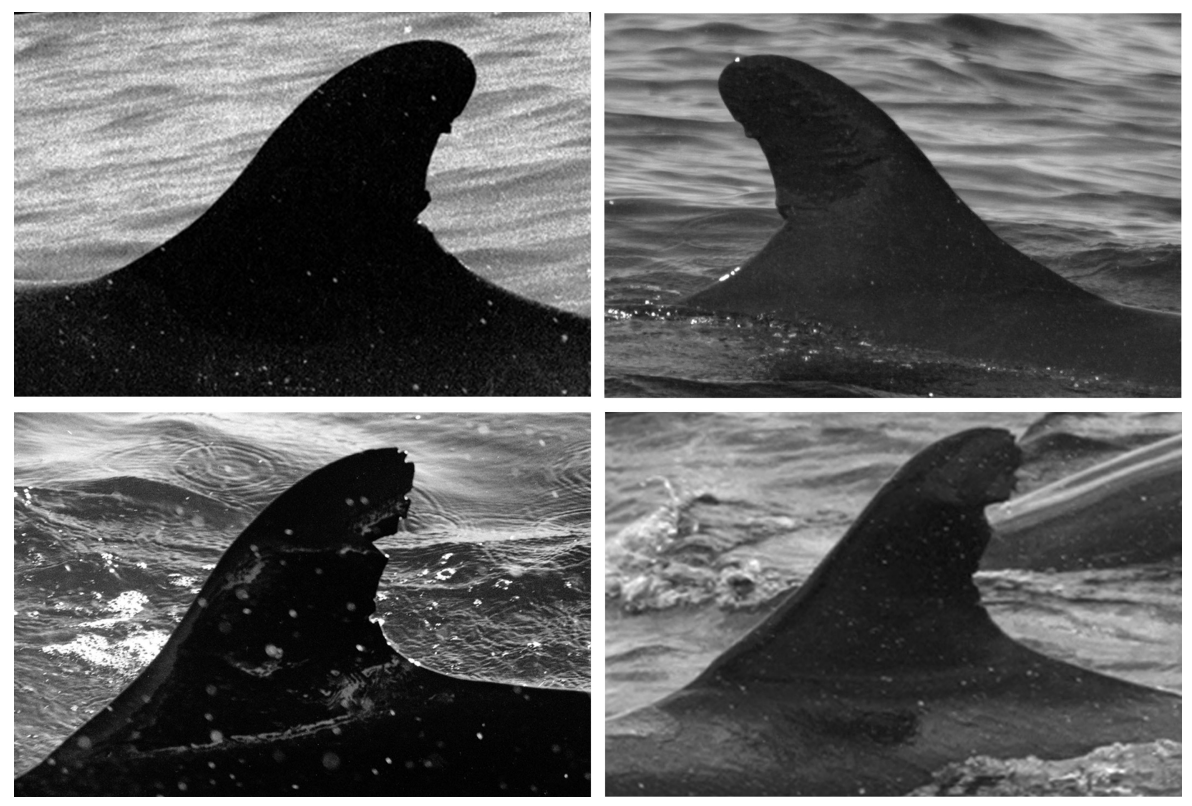

Figure 3. Examples of marks and photo qualities used in matching and assigning distinctiveness ratings. Top. Distinctive individual (HIPc138) seen 31 December 1988 (left photo) off the island of Hawai i (photo quality "excellent") and 3 March 2005 (right photo) in the 4-island area (photo quality "good"). One mark change occurred between these two periods, with the upper edge of the lower notch smoothing out. Bottom. Very distinctive individual (HIPc115) seen 1 February 1998 (left photo) off the island of Hawai'i (photo quality "excellent") and 11 April 2006 (right photo) in the 4-island area (photo quality "good"). One new notch (lowest on right photo), and changes in notch shape were documented between the two sightings. 
Table 2. Number of false killer whale identifications and individuals by area.

\begin{tabular}{|c|c|c|c|c|c|}
\hline $\begin{array}{l}\text { Island } \\
\text { area }\end{array}$ & $\begin{array}{c}\text { \# IDs of } \\
\text { marked } \\
\text { individuals }\end{array}$ & $\begin{array}{l}\text { \# individuals } \\
\text { (excluding } \\
\text { within-area } \\
\text { resightings) }\end{array}$ & $\begin{array}{l}\#(\%) \\
\text { individuals } \\
\text { resighted }\end{array}$ & $\begin{array}{l}\text { \# within-area } \\
\text { within-year } \\
\text { resightings }\end{array}$ & $\begin{array}{c}\text { \# within-area } \\
\text { between year } \\
\text { resightings }\end{array}$ \\
\hline Kaua'i & 1 & 1 & 0 & $\mathrm{n} / \mathrm{a}$ & $\mathrm{n} / \mathrm{a}$ \\
\hline O'ahu & 23 & 22 & $20(90.9)$ & $\mathrm{n} / \mathrm{a}$ & 1 \\
\hline 4-islands & 117 & 56 & $38(67.8)$ & 12 & 49 \\
\hline Hawai'i & 171 & 111 & $60(54.1)$ & 28 & 32 \\
\hline Palmyra & 1 & 1 & 0 & $\mathrm{n} / \mathrm{a}$ & $\mathrm{n} / \mathrm{a}$ \\
\hline
\end{tabular}

Analyses are restricted to distinct and very distinct individuals with good or excellent quality photos.

Comparisons between the main Hawaiian Islands and Palmyra/offshore were undertaken using all photo qualities and distinctiveness ratings, but there were no matches of individuals from the main Hawaiian Islands to Palmyra/offshore. For assessment of movements among the main Hawaiian Islands, only distinctive and very distinctive individuals with photo quality ratings of good and excellent were used. Of the 80 individuals seen more than once, 37 (46.2\%) were seen at two or more islands. There was only one distinctive individual with a sufficient quality photo documented off Kaua ' $i$, and this individual was not seen off any other island. For the islands of $\mathrm{O}^{\prime} \mathrm{ahu}$, the 4-island area, and Hawai' $\mathrm{i}$, there were sufficient identifications to address inter-island movements and for the latter two areas, within-area resighting rates. There were numerous within-area resightings for both the 4-island area and Hawai $i$ (Table 2). Distances among the closest sightings for each of the areas were $85.8 \mathrm{~km}$ (4-islands to Hawai'i), $164 \mathrm{~km}$ (4-islands to O'ahu), and $254 \mathrm{~km}$ (O'ahu to Hawai'i). The highest proportion of individuals moving among areas was between O'ahu and Hawai'i (Table 3), with 18 of the 20 individuals (90\%) from O'ahu seen on more than one occasion also documented off Hawai' $i$ (distances among resighting locations from O'ahu to Hawai' $\mathrm{i}$ were from 254 to $283 \mathrm{~km}$ ). However, 17 of these 20 individuals were seen together in a single group off O'ahu (in 2003) and most were associated when these individuals were sighted off Hawai' $i$ (in 2004), albeit in several encounters with small numbers of individuals identified in each encounter (Table 4). Thus the high proportion of individuals moving from O'ahu to Hawai' $\mathrm{i}$ may largely represent the movements of one or two cohesive groups of individuals

Table 3. Proportion of individuals documented moving among islands, considering only distinctive and very distinctive individuals with good or excellent quality photographs.

\begin{tabular}{lccc}
\hline \hline Island area & $\begin{array}{c}\text { \# individuals seen }>1 \\
\text { (from Table 2) }\end{array}$ & $\begin{array}{c}\text { \# (\%) documented } \\
\text { at other islands }\end{array}$ & $\begin{array}{c}\text { \# inter-island } \\
\text { movements represented }\end{array}$ \\
\hline O'ahu & 20 & $19(95.0)$ & 19 \\
4-islands & 38 & $20(52.6)$ & 27 \\
Hawai'i & 60 & $36(60.0)$ & 42 \\
\hline
\end{tabular}

Inter-island movements were counted for both directions (e.g., an individual matched between $\mathrm{O}^{\prime}$ ahu and Hawai' $\mathrm{i}$ was counted under the totals for both rows), and individuals moving from one island to another, and back, are counted twice. 
Table 4. Identified false killer whales encountered off O'ahu (26 May 2003) and off the island of Hawai i (all 2004 dates), illustrating movement of 17 individuals between islands. Only distinctive and very distinctive individuals with good or excellent quality photos are shown.

\begin{tabular}{|c|c|c|c|c|c|}
\hline \multirow[b]{2}{*}{ Whale ID \# } & \multicolumn{5}{|c|}{ Encounter date } \\
\hline & 26 May 03 & 13 Sep 04 & 6 Oct 04 & 27 Nov 04 & 3 Dec 04 \\
\hline HIPc133 & & $\mathrm{x}$ & & & \\
\hline HIPc143 & & $\mathrm{x}$ & & & \\
\hline HIPc151 & & $\mathrm{x}$ & & & \\
\hline HIPc156 & $\mathrm{x}$ & & & & \\
\hline HIPc157 & $\mathrm{x}$ & & $\mathrm{x}$ & & \\
\hline HIPc159 & $\mathrm{x}$ & $\mathrm{x}$ & & $\mathrm{x}$ & $\mathrm{x}$ \\
\hline HIPc160 & $\mathrm{x}$ & & & & \\
\hline HIPc161 & $\mathrm{x}$ & $\mathrm{x}$ & & & \\
\hline HIPc162 & $\mathrm{x}$ & & & $\mathrm{x}$ & $\mathrm{x}$ \\
\hline HIPc163 & $\mathrm{x}$ & & $\mathrm{x}$ & & \\
\hline HIPc164 & $\mathrm{x}$ & $\mathrm{x}$ & & & $\mathrm{x}$ \\
\hline HIPc 165 & $\mathrm{x}$ & & & $\mathrm{x}$ & \\
\hline HIPc166 & $\mathrm{x}$ & $\mathrm{x}$ & $\mathrm{x}$ & $\mathrm{x}$ & \\
\hline HIPc167 & $\mathrm{x}$ & $\mathrm{x}$ & $\mathrm{x}$ & & \\
\hline HIPc168 & $\mathrm{x}$ & & $\mathrm{x}$ & $\mathrm{x}$ & \\
\hline HIPc169 & $\mathrm{x}$ & $\mathrm{x}$ & $\mathrm{x}$ & $\mathrm{x}$ & \\
\hline HIPc170 & $\mathrm{x}$ & $\mathrm{x}$ & $\mathrm{x}$ & & \\
\hline HIPc171 & $\mathrm{x}$ & $\mathrm{x}$ & $\mathrm{x}$ & & \\
\hline HIPc172 & $\mathrm{x}$ & $\mathrm{x}$ & $\mathrm{x}$ & & \\
\hline HIPc173 & $\mathrm{x}$ & $\mathrm{x}$ & $\mathrm{x}$ & & \\
\hline HIPc174 & $\mathrm{x}$ & & $\mathrm{x}$ & $\mathrm{x}$ & \\
\hline HIPc177 & $\mathrm{x}$ & $\mathrm{x}$ & & & \\
\hline HIPc179 & & $\mathrm{x}$ & & & \\
\hline HIPc181 & & $\mathrm{x}$ & & & \\
\hline HIPc184 & & & & $\mathrm{x}$ & \\
\hline HIPc186 & & $\mathrm{x}$ & $\mathrm{x}$ & & \\
\hline HIPc187 & & $\mathrm{x}$ & $\mathrm{x}$ & & \\
\hline HIPc188 & & $\mathrm{x}$ & $\mathrm{x}$ & & \\
\hline HIPc189 & & $\mathrm{x}$ & & & $\mathrm{x}$ \\
\hline HIPc192 & & & $\mathrm{x}$ & $\mathrm{x}$ & \\
\hline
\end{tabular}

among the islands (see below). Half of the individuals (50\%, 19 of 38) from the 4-island area that were seen on more than one occasion were also recorded off Hawai' $\mathrm{i}$ (distances among resighting locations from the 4-island area to Hawai' $\mathrm{i}$ were from 116 to $155 \mathrm{~km}$ ). Despite the relative proximity of O'ahu and the 4-island area, only 2 of 20 individuals (10\%) from O'ahu seen on more than one occasion were also documented in the 4-island area.

Intervals between resightings of individuals, and from when an individual was first seen to when it was last seen, were calculated for the 80 distinct and very distinct individuals with good or excellent quality photos. Resighting intervals ranged from 5 to 6,681 d (18.3 yr), with a median resighting interval of $407 \mathrm{~d}(1.1 \mathrm{yr}$, $n=160$ intervals). The interval between first and last sightings of an individual ranged from 12 to $7,350 \mathrm{~d}(20.1 \mathrm{yr})$, with a median interval of $557 \mathrm{~d}(1.53 \mathrm{yr}$, 
$n=80$ individuals). Mark change was examined for these 80 individuals. Twenty-six individuals had changes in either the number of notches on the dorsal fin or the shape of notches. Six individuals were documented with two or more changes in notch number or shape occurring independently, i.e., changes were noted on different resighting occasions, thus a minimum of 36 mark changes occurred. Assuming that all changes for individuals with more than one new notch or both a new notch and a change in notch shape were independent, the maximum number of mark changes that occurred for these individuals was 46. The rate of mark change was calculated using the sum of all resighting intervals (317.7 yr) and the minimum (36) and maximum (46) number of changes. Marks were estimated to change, or new marks were added, an average of once every 6.9 to $8.8 \mathrm{yr}$. These rates likely underestimate the actual rate of mark change, as some individuals may have mark changes so great that they are misidentified and considered new individuals, or may have two changes affecting the same mark in between resightings. The likelihood of having mark changes so great that individuals are misidentified is probably small, given the number of marks used to match individuals (see above, Fig. 3).

Seasonal distribution of resightings was assessed for those individuals seen on four or more occasions ( $n=21$ individuals). Only two of the 21 individuals were seen exclusively in a single oceanographic season, nine were documented in two oceanographic seasons (four of which spanned nonadjacent seasons), and 10 were seen in three seasons. On average these individuals were seen 4.90 times $(\mathrm{SD}=1.37)$ in 4.00 different months $(\mathrm{SD}=0.71)$. The seasonal distribution of encounters and identifications varied considerably, with $16.3 \%-39.0 \%$ of the identifications occurring in different seasons, thus the likelihood of resightings being evenly distributed among the four seasons was small.

Social networks were constructed of animals identified around the main Hawaiian Islands for all individuals at least slightly distinctive or greater, and with all photo qualities (Fig. 4). Of the 194 individuals documented around the main Hawaiian Islands, $168(86.6 \%)$ were linked by association in a single social network. Of the 26 individuals not linked to the large association cluster, seven (3.5\%) were identified in five different encounters, where only one or two individuals per encounter were identified. These included the only two individuals identified off Kaua' $i$, two individuals in the 4-island area, and three individuals off Hawai' $i$. The remaining 19 individuals $(9.7 \%)$ were documented in three subgroups on a single day, spread out from 42 to $70 \mathrm{~km}$ offshore of the island of Hawai' $\mathrm{i}$ (Fig. 2). Although spread out over $28 \mathrm{~km}$, these three subgroups are considered here as a single encounter, given all individuals were moving in the same direction, and within a single subgroup individuals were spread over $>5 \mathrm{~km}$. Not including the encounters $>1,000 \mathrm{~km}$ from the Hawaiian Islands, this group was the farthest from shore documented around the islands. A social network restricted to distinctive and very distinctive individuals with photo qualities of good or excellent indicated the same pattern (not shown). Of 152 individuals documented, 132 (86.8\%) were linked by association in a single cluster, four individuals $(2.6 \%)$ were seen alone or in a pair, and 16 individuals $(10.5 \%$; the group found farthest offshore) were found in a single cluster not linked with any other groups.

Forty-one individuals were seen three or more times (maximum $=8$ ). Several factors suggest that not all distinctive individuals within groups were photo-identified, influencing our association analyses. As noted above, many encounters were terminated due to inclement weather or time of day, groups were often spread out over extensive areas, and particularly for short duration and opportunistic efforts, it is likely that not 


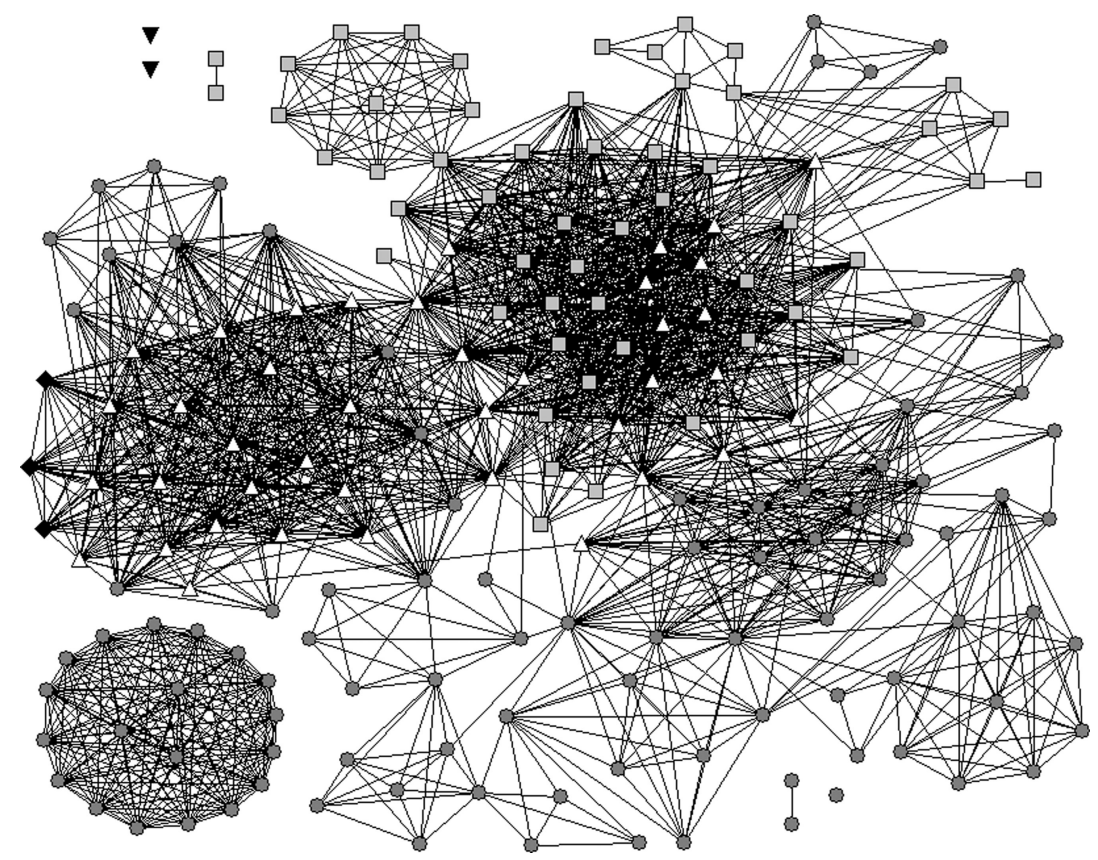

Figure 4. A social network diagram showing associations among individual false killer whales documented around the main Hawaiian Islands. All individuals considered slightly distinctive, distinctive, or very distinctive, are shown. Nodes in the network represent individuals, while lines between individuals represent associations within a group. Symbol shapes and shading indicate islands individuals were identified: black inverted triangles $=$ Kaua $i$ only; medium gray circles $=$ Hawai $i$ i only; light gray squares $=4$-islands only; black diamonds $=$ $\mathrm{O}^{\prime}$ ahu only; white triangles $=$ two or more islands. The lone cluster of 19 individuals was a group documented spread from $42-70 \mathrm{~km}$ off the island of Hawai' $i$. Other than this group, all groups of three or more were linked by association to the largest cluster.

all subgroups were approached for photo-identification. Group size estimates from directed efforts were greater (median $=15$ ) than the number of identifications of distinctive and very distinctive individuals (median $=6$ ) photo-identified. Association values are thus likely negatively biased. Mean association values for the 41 individuals seen three or more times was $0.12(\mathrm{SD}=0.06)$. The mean of the maximum association values for each individual was $0.64(\mathrm{SD}=0.24)$, indicating that many individuals had strong associations. Associations among individuals illustrated in a sociogram (Fig. 5) indicate that associations were nonrandom and distinct clustering of individuals was apparent. Tests for preferred/avoided companions were significant $(P=0.99995)$, indicating that individuals associated preferentially with certain other individuals, rather than associating at random based on availability (within periods of a year). Repeated associations among individuals were documented; the longest repeated association was of two individuals seen together six times over a 15.1-yr period (5,506 d). These two individuals were documented without the other on a total of five occasions. However, on two of these occasions only two individuals in the group were photo-identified, so the probability of documenting a repeated association was low. 

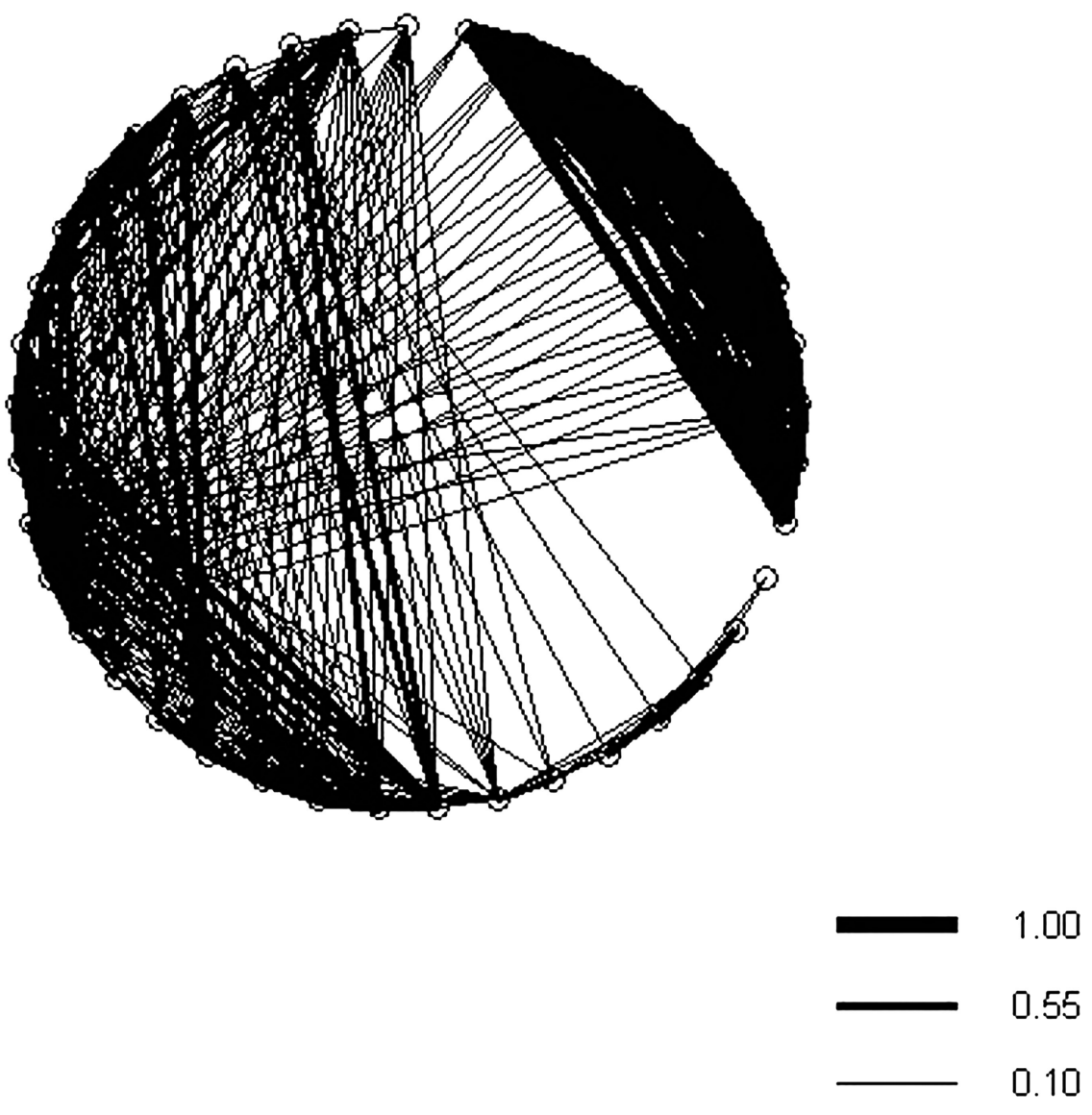

Figure 5. A sociogram showing strength of associations (represented by the thickness of the connecting lines) among distinctive and very distinctive false killer whales (represented as points on the outside of the circle) seen three or more times. Individual ID labels are excluded due to space limitations. Association index values determined using a simple-ratio index of association.

\section{DISCUSSION}

Our study is the first long-term investigation of false killer whale site fidelity and association patterns, and one of only a few studies based on individual identification of this species anywhere. In their study off Costa Rica, Acevedo-Guitierrez et al. (1997) noted repeated sightings of individual false killer whales over periods of up to 2 yr. In their study area, false killer whales were encountered extremely infrequently ( 15 sightings in over $600 \mathrm{~d}$ on the water). Although our survey coverage and levels of directed effort were also extensive $(38,434 \mathrm{~km}$ of trackline in $369 \mathrm{~d}$ on the water, over an approximately $17,000-\mathrm{km}^{2}$ study area), false killer whales were only infrequently encountered around the main Hawaiian Islands, representing just $1.46 \%$ of odontocete sightings that were not cued by radio calls from other vessels. Despite the low encounter rate, individual photo-identification demonstrated that 
almost half (45.4\%) of the individuals were seen in more than $1 \mathrm{yr}$, and more than half $(52.6 \%)$ were seen on more than one occasion. On average, about $77 \%$ of the distinctive individuals identified within any particular group were seen on multiple occasions. Given the 21-yr span of the study and expected births and deaths in the population (limiting the potential for resightings), such evidence implies both that the population of false killer whales around the main Hawaiian Islands is relatively small, and that individuals show considerable fidelity to the islands. Resightings of individuals spanned the entire 21-yr duration of our study, indicating that such fidelity is stable over periods of many years.

Genetic evidence from many of the groups documented in directed efforts demonstrate that false killer whales found near-shore around the main Hawaiian Islands are demographically isolated from those sampled offshore in the tropical Pacific (Chivers et al. 2007), implying that fidelity to the islands has occurred over periods long enough for evidence of genetic isolation to evolve. As noted by Chivers et al. (2007), there is similar evidence for a number of other species of odontocetes in Hawaiian waters being demographically isolated from open-ocean populations, including spinner dolphins, Stenella longirostris (Galver 2002, Andrews et al. 2006), short-finned pilot whales (Chivers et al. 2003), and bottlenose dolphins (Martien and Baird 2006). The factors that may encourage the evolution of island-associated populations may be similar for all of these species; the central tropical Pacific is oligotrophic, and the oceanographic influence of the islands increases productivity immediately around the islands (Doty and Oguri 1956, Gilmartin and Revelante 1974, Seki et al. 2001, 2002), and reduces the spatial and temporal variability in prey availability. False killer whales around the main Hawaiian Islands had previously been recorded feeding on mahi mahi and yellowfin tuna (Brown et al. 1966, Shallenberger 1981, Connor and Norris 1982). Because of their tendency to carry prey items for extended periods and share prey (Brown et al. 1966, Connor and Norris 1982; Baird, personal observations), surface observations of predation may be less biased for this species than for most other species of cetaceans. Our observations of predation also suggest that false killer whales around the main Hawaiian Islands feed primarily on large pelagic fish, particularly mahi mahi. The islands are known to aggregate large pelagic fish such as tunas, billfish, and mahi mahi (Itano and Holland 2000, Seki et al. 2002, Dagorn et al. 2007). Sighting depth comparisons among all documented odontocete species indicate that false killer whales use the greatest range of water depths of all species (Baird, unpublished data). Such habitat variability reflects the wide ranging movements and diverse habitats used by their prey (Itano and Holland 2000, Dagorn et al. 2007).

Chivers et al. (2007) note that false killer whales sampled within the Hawaiian EEZ but far from the main Hawaiian Islands have mitochondrial haplotypes the same as or closely related to false killer whales sampled elsewhere in the eastern North Pacific, but that boundaries between the island-associated population and the "offshore" population are not known. Several authors have suggested that false killer whales in some parts of their range may exhibit seasonal inshore-offshore movements (Tomilin 1967, Kasuya 1971). There are two unsubstantiated reports of groups moving long distances: Nishiwaki (1967) reported a group following a tuna vessel for approximately $1,600 \mathrm{~km}$, and van Beneden (1889, cited in Tomilin 1967) reported a group following a vessel from Brazil to the English Channel. However, there is no published information on movements based on tagging or photo-identification of distinctive individuals. While we were not able to assess seasonality in relation to effort, photographic resightings of individuals were typically spread over multiple 
oceanographic seasons, implying there is no strong seasonal component to their use of the main Hawaiian Islands. We documented movements of individuals up to 283 km (from O'ahu to Hawai'i) using photo-identification resightings, a relatively small distance for what might be expected for an open-ocean species. It should be noted however, that our sample of identification photographs at greater distances was extremely small (only two distinctive individuals, Table 1). As such, it is reasonable to assume that false killer whales around the main Hawaiian Islands likely move much greater distances, at least along the Hawaiian Island chain, but also potentially offshore. We did not obtain genetic samples from the group documented $42-70 \mathrm{~km}$ offshore of the island of Hawai' $i$ (Fig. 2), but the fact that none of these individuals were documented associating with the large social network of animals documented near-shore around the main Hawaiian Islands (Fig. 4) implies that offshore false killer whales may move to within at least $42 \mathrm{~km}$ of the islands. With only a single observation of a large group not associating with the island social network, further research effort in areas where the island-associated and offshore populations potentially overlap, or satellite-tagging of individuals in offshore waters, is required to confirm how close the offshore population may come to the main Hawaiian Islands. Determining the offshore range of the island-associated population, and the degree of overlap of the two putative populations, is important for management, as levels of bycatch in the Hawai' $\mathrm{i}$-based longline fishery may not be sustainable (Carretta et al. 2006).

While the "island-associated" population regularly used shallow ( $<200 \mathrm{~m}$ depth) waters in the 4-island area (Fig. 2), our analyses of sighting rates by depth (Fig. 1) suggest that even these island-associated individuals showed a preference for deeper $(>3,000 \mathrm{~m})$ waters around the main Hawaiian Islands. This apparent preference for deeper waters, combined with the focus of most research effort in shallower waters, may explain in part the relatively low sighting rates for this species, despite the high individual resighting rates. In addition, more than half of the individuals that were resighted were documented moving among the islands, over distances of up to $283 \mathrm{~km}$. Due to their large size, dispersed groups, and frequent aerial activity, false killer whales are one of the easier species of odontocetes to detect at a distance, thus the probability of missing them during survey efforts is relatively low. The low sighting rates may reflect a combination of low density of individuals, preferences for deeper areas, and the movements of individuals to other islands during survey efforts focused only off a single island.

While movements of individuals among islands were frequent, the proportion of individuals from each island documented moving to other islands was not correlated with the distances among islands. In particular, virtually all of the false killer whales documented off $\mathrm{O}^{\prime}$ ahu ( $90 \%$ of those seen more than once) were also recorded off Hawai' $\mathrm{i}$, at distances ranging from 254 to $283 \mathrm{~km}$, yet only a small proportion (10\% of those seen more than once) were documented in the 4-island area, a distance of only $164 \mathrm{~km}$ (Fig. 2). While our sample size of encounters and identifications off $\mathrm{O}$ 'ahu is relatively small, this suggests that within the island-associated population, individuals may show preference for particular types of habitat. There are differences among the islands in available shallow-water habitat, with the bathymetry off $\mathrm{O}^{\prime}$ ahu and Hawai'i being more similar to each other (i.e., steep slope with deep water close to shore) than either are to the relatively shallow 4-island area. How such habitats influence potential prey populations is not known (but see Itano and Holland 2000). Such within-population variation in foraging habitats has been documented for mammal-eating killer whales (Orcinus orca), with some groups foraging preferentially in near-shore areas and around seal haul-outs, and other groups foraging in 
open water, despite the fact that both feed on the same prey species (Baird and Dill 1995).

Little is known of the social organization of false killer whales. Based on their tendency to mass strand, and the apparent reluctance of individuals to return to deeper water when one individual is in distress (Porter 1977), false killer whales are thought to have strong social bonds. Food sharing in the wild has been previously reported (Connor and Norris 1982) and was frequently observed during this study (unpublished data). Genetic analyses where multiple individuals within a group were sampled usually showed multiple mitochrondrial haplotypes within groups (Chivers et al. 2007), indicating that groups often contain multiple matrilines. As noted above, our association analyses were limited by photographically sampling only a portion of individuals in most groups. The long time frame of our study and associated births and deaths also mean that we likely underestimate levels of association among individuals. Regardless, the high maximum association values, nonrandom associations (Fig. 5), and repeated associations over periods of up to $15 \mathrm{yr}$, all imply that false killer whales have relatively stable bonds among individuals. Thus social organization of false killer whales appears more similar to that of killer whales (Bigg et al. 1990, Baird and Whitehead 2000) or pilot whales (Ottensmeyer and Whitehead 2003), rather than exhibiting a fission-fusion social organization as documented for some other odontocete species (e.g., Connor et al. 2000). Large groups encountered in the field likely represent temporary associations among a number of smaller, relatively stable subgroups (see e.g., Fig. 5), however, determining the composition of these more stable subgroups will require repeated encounters with a number of groups.

In theory, sociality is likely driven either by predation pressure or in relation to foraging, although such forces would not necessarily lead to the apparently longterm and at least somewhat stable associations we documented. For false killer whales, predators should include killer whales and large sharks, although predation on this species has not been reported. What might lead to stable long-term associations are the benefits of cooperative hunting. As noted, false killer whales in Hawaiian waters appear to feed primarily on large pelagic fish such as mahi mahi, yellowfin tuna and occasionally, swordfish, and prey are regularly shared among individuals. All of these species are extremely fast swimming and potentially difficult to capture, and at least in the case of swordfish may also pose a risk to a predator. As with mammaleating killer whales, the benefits of cooperatively hunting large, difficult-to-capture, or potentially dangerous prey (Baird and Dill 1996) with familiar and consistent hunting partners may lead to stable associations (Baird and Whitehead 2000). It is also possible that provisioning related individuals, as has been documented for fish-eating killer whales (Ford and Ellis 2006), or assisting with the care of related calves within groups, could result in selection for stable groups. With a species encountered as infrequently as false killer whales, understanding social organization in more detail will require long-term studies. While false killer whales do exhibit some sexual dimorphism in head shape (Mead 1975), it is not possible to determine sex in the field or from typical photographs obtained in encounters. Assessment of the genetic relatedness of individuals within groups from remote skin biopsies would help in teasing apart the details of social structure.

Despite the low encounter rates and apparent preference for deep $(>3,000 \mathrm{~m})$ waters, our results indicate a relatively small population of false killer whales that exhibit long-term fidelity to the main Hawaiian Islands. As noted, there is genetic evidence that this population is demographically isolated from false killer whales in offshore waters of the Hawaiian EEZ and the broader waters of the tropical Pacific 
(Chivers et al. 2007). These features combined indicate that this population is susceptible to impacts from anthropogenic activities (e.g., Warkentin and Hernandez 1996, Brager et al. 2002). The high degree of dorsal fin disfigurements documented for this population (Baird and Gorgone 2005) suggests that, at least at some point in the past, individuals within the population likely have interacted with the longline fishery. While the extent of their offshore movements are unknown, individuals have been documented moving up to $283 \mathrm{~km}$ among the main Hawaiian Islands, thus it is certainly possible that they may move far enough offshore $(\sim 46 \mathrm{~km})$ to interact with the longline fishery. Additionally, interactions with inshore troll and hand-line fisheries may also occur (Nitta and Henderson 1993). Assessing trends in abundance will be problematic for the island-associated population due to the difficulty in accurately estimating the abundance for a small population (Taylor et al. 2007). Abundance estimates from line-transect surveys have especially high variance when encounter rates are low. Capture-recapture estimates of abundance based on photo-identification would be more precise. With the high resighting rates we have documented, the variance associated with capture-recapture estimates would be lower than that of line-transect estimates, thus increasing the likelihood of being able to detect population trends.

\section{CONCLUSION}

False killer whales around the main Hawaiian Islands clearly form a distinct, islandassociated population. This conclusion is supported both by the high rate at which individuals are resighted and the long time period over which the same individuals have been seen. These results are also supported by previous genetic studies (Chivers et al. 2007). Inter-island movements were common and individuals were found to move up to $283 \mathrm{~km}$ between subsequent sightings. However, we found that one group of animals encountered only $42 \mathrm{~km}$ offshore showed no associations with those seen closer to the islands. It appears that false killer whales are another of the growing list of pelagic cetacean species that can form strong associations with island ecosystems, and local populations of these species can essentially become island specialists.

\section{ACKNOWLEDGMENTS}

We would like to thank Chris Bane, Phillip Colla, Tori Cullins, Tara Leota, Adam Frankel, and Doug Perrine for providing identifications from Kaua i (CB, TL), O'ahu (TC), Maui (PC), and Hawai'i (AF, DP), Jim Cotton, Chris Cutler, Beth Goodwin, Susanne Yin, and Sophie Webb for collecting photos during the PICEAS cruise, and Jeremy Davies and Andrea Havron for GIS processing of effort and sighting data. Annie Douglas helped confirm matches. Field work for directed efforts around the main Hawaiian Islands was funded by the Southwest Fisheries Science Center, U.S. Navy (N45), Pacific Islands Fisheries Science Center, Wild Whale Research Foundation, Dolphin Quest, and the U.S. Marine Mammal Commission. DRS would like to thank UFO Chuting, Central Pacific Marine, and the Whale Quest Kapalua Program. MHD would like to thank Dan Gubitz and Amanda Cummins. Russel Ito and Kurt Kawamoto assisted with identification of fish prey from photographs. Directed odontocete surveys were undertaken under NMFS Scientific Research Permit No. 731. We thank Susan Chivers, Annie Douglas, Rus Hoelzel, Gretchen Steiger, and two anonymous reviewers for helpful comments on the manuscript. 


\section{LITERATURE CITED}

ACevedo-Guitiérrez, A., B. Brennan, P. Rodriguez and M. Thomas. 1997. Resightings and behavior of false killer whales (Pseudorca crassidens) in Costa Rica. Marine Mammal Science 13:307-314.

ANDREWs, K. R., L. KARCZMARSKI, W. W. L. Au, S. H. RiCKARDS, C. A. VANDERLIP AND R. J. ToONEN. 2006. Patterns of genetic diversity of the Hawaiian spinner dolphin (Stenella longirostris). Atoll Research Bulletin 543:65-73.

BAIRD, R. W., AND L. M. Dill. 1995. Occurrence and behaviour of transient killer whales: Seasonal and pod-specific variability, foraging behaviour and prey handling. Canadian Journal of Zoology 73:1300-1311.

BAIRD, R. W., AND L. M. DiLl. 1996. Ecological and social determinants of group size in transient killer whales. Behavioral Ecology 7:408-416.

BAIRD, R. W., AND H. WHITEHEAD. 2000. Social organization of mammal-eating killer whales: Group stability and dispersal patterns. Canadian Journal of Zoology 78:20962105.

BAIRD, R. W., AND A. M. GORGONE. 2005. False killer whale dorsal fin disfigurements as a possible indicator of long-line fishery interactions in Hawaiian waters. Pacific Science 59:593-601.

BARLOW, J. 2006. Cetacean abundance in Hawaiian waters estimated from a summer/fall survey in 2002. Marine Mammal Science 22:446-464.

BARLOW, J., AND S. RANKIN. 2007. False killer whale abundance and density: Preliminary estimates for the PICEAS study area south of Hawai' $i$ and new estimates for the US EEZ around Hawai i. Southwest Fisheries Science Center Administrative Report LJ-07-02. $15 \mathrm{pp}$.

BejDer, L., D. Fletcher AND S. BRÄGER. 1998. A method for testing association patterns of social animals. Animal Behaviour 56:719-725.

BeYer, H. L. 2004. Hawth's analysis tools for ArcGIS. Version 3.21. Available from http://www.spatialecology.com/htools (accessed 12 September 2005).

BigG, M. A., P. F. Olesiuk, G. M. Ellis, J. K. B. Ford AND K. C. BAlComb. 1990. Social organization and genealogy of resident killer whales (Orcinus orca) in the coastal waters of British Columbia and Washington State. Report of the International Whaling Commission (Special Issue 12):383-405.

Bräger, S., S. M. DAwson, E. Slooten, S. Smith, G. S. Stone and A. YoshinaGa. 2002. Site fidelity and along-shore range in Hector's dolphin, an endangered marine dolphin from New Zealand. Biological Conservation 108:281-287.

BRown, D. H., D. K. CALDWELL AND M. C. CALDWELl. 1966. Observations on the behavior of wild and captive false killer whales, with notes on associated behavior of other genera of captive delphinids. Los Angeles County Museum Contributions in Science 95:2-32.

CAirns, S. J., AND S. J. SCHWAGER. 1987. A comparison of association indices. Animal Behaviour 35:1454-1469.

Carretta, J. V., K. A. Forney, M. M. Muto, J. Barlow, J. Baker, B. Hanson And M. S. LOWRY. 2006. U.S. Pacific marine mammal stock assessments: 2005. NOAA Technical Memorandum NMFS-SWFSC-388. 317 pp.

Chivers, S. J., R. G. LedUC AND R. W. BAIRD. 2003. Hawaiian Island populations of false killer whales and short-finned pilot whales revealed by genetic analyses. Page 32 in Abstracts of the 15th Biennial Conference on the Biology of Marine Mammals, Greensboro, NC, 14-19 December 2003.

Chivers, S. J., R. W. Baird, D. J. Mcsweeney, D. L. Webster, N. M. Hedrick and J. C. SALINAS. 2007. Genetic variation and evidence for population structure in eastern North Pacific false killer whales (Pseudorca crassidens). Canadian Journal of Zoology 85:783794.

CONNOR, R. C., AND K. S. NORRIs. 1982. Are dolphins reciprocal altruists? American Naturalist 119:358-374. 
Connor, R. C., R. S. Wells, J. MAnn And A. J. Read. 2000. The bottlenose dolphin: Social relationships in a fission-fusion society. J. Mann, R. C. Connor, P. L. Tyack, and H. Whitehead, eds. Pages 91-126 in Cetacean societies: Field studies of dolphins and whales. University of Chicago Press, Chicago, IL.

DAgOrN, L., K. N. Holland AND D. G. ITANO. 2007. Behavior of yellowfin (Thunnus albacares) and bigeye ( $T$. obesus) tuna in a network of fish aggregating devices (FADs). Marine Biology 151:595-606.

Doty, M. S., AND M. OGURI. 1956. The island mass effect. Journal du Conseil-Conseil International pour l'Exploration de la Mer 22:33-37.

Flament, P. 1996. The ocean atlas of Hawai'i. University of Hawai'i. Available from http://radlab.soest.hawaii.edu/atlas/.

FORD, J. K. B., AND G. M. ELLIS. 2006. Selective foraging by fish-eating killer whales Orcinus orca in British Columbia. Marine Ecology Progress Series 316:185-199.

FORNEY, K. A., AND D. KOBAYASHI. 2007. Updated estimates of mortality and injury of cetaceans in the Hawai'i-based longline fishery, 1994-2005. NOAA Technical Memorandum NMFS-SWFSC $412.30 \mathrm{pp}$.

GALVER, L. 2002. The molecular ecology of spinner dolphins, Stenella longirostris: Genetic diversity and population structure. Ph.D. thesis, Scripps Institute of Oceanography, University of California, San Diego, CA. 192 pp.

Gilmartin, M., AND N. REVELANTE. 1974. The island mass effect on the phytoplankton and primary production of the Hawaiian Islands. Journal of Experimental Marine Biology and Ecology 16:181-204.

GinsberG, J. R., AND T. P. YOUNG. 1992. Measuring association between individuals or groups in behavioural studies. Animal Behaviour 44:377-379.

Hillman, G. R., B. Würsig, G. A. Gailey, N. Kehtarnavaz, A. Drobyshevsky, B. N. Araabi, H. D. Tagare and D. W. Weller. 2003. Computer-assisted photoidentification of individual marine vertebrates: A multi-species system. Aquatic Mammals 29:117-123.

ITANO, D. G., AND K. N. Holland. 2000. Movement and vulnerability of bigeye (Thunnus obesus) and yellowfin tuna (Thunnus albacares) in relation to FADs and natural aggregation points. Aquatic Living Resources 13:213-223.

KASUYA, T. 1971. Consideration of distribution and migration of toothed whales off the Pacific coast of Japan based on aerial sighting records. Scientific Reports of the Whales Research Institute, Tokyo 23:37-60.

Martien, K. K., AND R. W. BAIRD. 2006. Population structure of bottlenose dolphins around the main Hawaiian Islands revealed by mitochondrial and microsatellite marks. Document presented to the Pacific Scientific Review Group, National Marine Fisheries Service, La Jolla, CA, November 2006.

MCSWEENEY, D. J., R. W. BAIRD AND S. D. MAHAFFY. 2007. Site fidelity, associations and movements of Cuvier's (Ziphius cavirostris) and Blainville's (Mesoplodon densirostris) beaked whales off the island of Hawai'i. Marine Mammal Science 23:666-687.

MEAD, J. G. 1975. Anatomy of the external nasal passages and facial complex in the Delphinidae (Mammalia, Cetacea). Smithsonian Contributions to Zoology 207: $1-72$.

NishiwaKi, M. 1967. Distribution and migration of marine mammals in the North Pacific area. Bulletin of the Ocean Research Institute University of Tokyo 1:1-64.

NitTA, E. T., AND J. R. Henderson. 1993. A review of interactions between Hawai'i’s fisheries and protected species. Marine Fisheries Review 55:83-92.

Odell, D. K., AND K. M. MCClune. 1999. False killer whale Pseudorca crassidens (Owen, 1846).S. H. Ridgway and R. Harrison, eds. Pages 213-243 in Handbook of Marine Mammals. Volume 6. Academic Press, Orlando, FL.

OTTENSMEYER, C. A., AND H. WHITEHEAD. 2003. Behavioural evidence for social units in long-finned pilot whales. Canadian Journal of Zoology 81:1327-1338.

Porter, J. W. 1977. Pseudorca stranding. Oceans 10:8-15. 
Seki, M. P., J. J. Polovina, R. E. Brainard, R. R. Bidigare, C. L. Leonard and D. G. FOLEY. 2001. Biological enhancement at cyclonic eddies tracked with GOES thermal imagery in Hawaiian waters. Geophysical Research Letters 28:1583-1586.

SeKi, M. P., R. LumPKIN AND P. FlameNT. 2002. Hawai'i cyclonic eddies and blue marlin catches: The case study of the 1995 Hawaiian International Billfish Tournament. Journal of Oceanography 58:739-745.

SHALLENBERGER, E. W. 1981. The status of Hawaiian cetaceans. U.S. Marine Mammal Commission Report No. MMC-77/23. 79 pp.

STACEY, P. J., AND R. W. BAIRD. 1991. Status of the false killer whale, Pseudorca crassidens, in Canada. Canadian Field-Naturalist 105:189-197.

StACEY, P. J., S. LEATHERWOOD AND R. W. BAIRD. 1994. Pseudorca crassidens. Mammalian Species 456:1-6.

Taylor, B. L., M. Martinez, T. Gerrodette, J. Barlow and Y. N. Hrovat. 2007. Lessons from monitoring trends in abundance of marine mammals. Marine Mammal Science 23:157-175.

Tomilin, A. G. 1967. Cetacea. Mammals of the U.S.S.R. and adjacent countries. Volume 9. Israel Program for Scientific Translations, Jerusalem, Israel. 717 pp.

WARKENTIN, I. G., AND D. HERNÁNDEZ. 1996. The conservation implications of site fidelity: A case study involving nearctic-neotropical migrant songbirds wintering in a Costa Rican mangrove. Biological Conservation 77:143-150.

Received: 6 July 2007

Accepted: 12 February 2008 